\title{
Модели формирования института венчурных инвестиций
}

\section{Родионов И.И. ${ }^{23}$, Дмитриев Н.Н. ${ }^{24}$}

Цель данной статьи - рассмотрение наиболее важных вопросов, связанных с венчурным бизнесом в России. В статье анализируется российская венчурная модель, $в$ частности методь стимулирования государством создания института венчурного финансирования и роль участников рынка. Определены практические меры государственного участия в капитализачии венчурных фондов на основе частногосударственного партнерства.

Венчурный бизнес за последнее сорокалетие развился в мощную мировую индустрию и зарекомендовал себя как один из действенных инструментов финансовой поддержки и развития реального сектора экономики. Институт венчурного финансирования доказал свою эффективность в развитых странах. Успешный мировой опыт определяет роль государства и государственных программ поддержки развития венчурного предпринимательства (таких, как SBIC в CШA, Yozma - в Израиле, SITRA - в Финляндии и др.) как катализатора запуска самоподдерживающегося венчурного процесса [Аммосов Ю.П., 2005; Каширин А. И., 2007, рис.1]. В мире не было стран, ставших на путь инновационного развития, где роль государства в формировании данного института была незначительна. В США венчурный капитал к 2000 году превышал 60 млрд долл. [Симонян К. Э., 2006] и продолжает расти ускоренными темпами, несмотря на финансовый кризис, предлагая возможности альтернативных инвестиций.

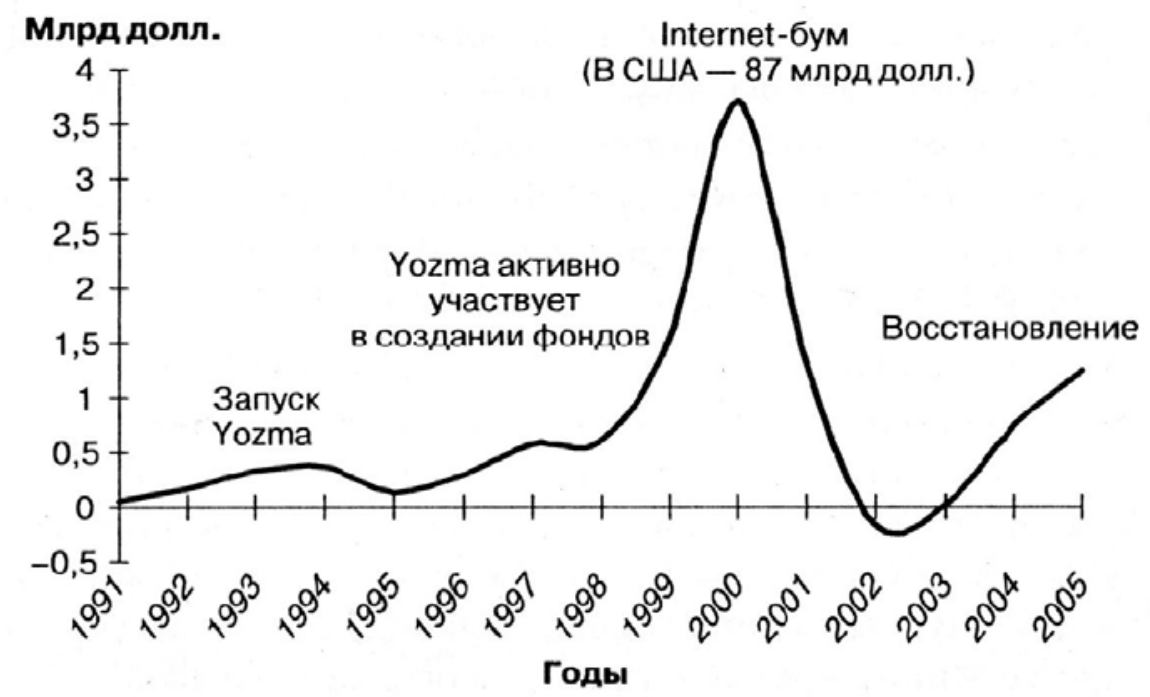

Рис. 1. Объем венчурных инвестиций в Израиле

Источник: Israeli Venture Association.

\section{Мировые примеры моделей построения венчурной индустрии}

На сегодняшний день можно наблюдать различные подходы и модели поддержки венчурного бизнеса, которые использовали в своей истории разные страны, их достижения и

\footnotetext{
${ }^{23}$ Родионов Иван Иванович, проф., д-р. эконом.. наук., преподаватель кафедры экономики и финансов фирмы ГУ-ВШЭ.

${ }^{24}$ Дмитриев Николай Николаевич, аспирант 2-го года обучения кафедры экономики и финансов фирмы ГУВШЭ.
} 
ошибки. Можно привести несколько моделей, которые являются показательными с точки зрения успешности.

\section{CШA - SBIC (The Small Business Investment Company)}

Рынок США характеризуется высокоразвитой инфраструктурой венчурного инвестирования и является самым большим рынком венчурного капитала в мире. Наблюдается высокая активность и ведущая роль как частного бизнеса, бизнес-ангелов, так и пенсионных фондов и страховых компаний. В США накоплен уникальный опыт развития и ведения венчурного бизнеса. В стране действует развитая законодательная база, которая имеет почти 80-летнюю историю, используется широкий спектр инструментов: налоговых льгот, кредитов, гарантируемых займов.

Программа компании по инвестициям в малый бизнес (далее - программа КИМБ) или Small Business Investment Companies (SBIC) - уникальная программа государственночастного партнерства, посредством которой с момента учреждения программы было осуществлено инвестирование в более чем 100000 малых американских предприятий в объеме 48 млрд долл. США.

КИМБ - это учрежденные и управляемые частными лицами венчурные компании, лицензируемые Администрацией малого бизнеса (далее - АМБ США) или U.S. Small Business Administration (SBA) в целях предоставления этим компаниям инвестиций в акционерный капитал или предоставления долгосрочных займов. АМБ США была создана в 1953 году как независимое агентство федерального правительства с целью оказания помощи, консультирования и содействия развитию проектов в сфере малого бизнеса.

Программа КИМБ учреждена на основе принятого Американским Конгрессом в 1958 году Акта об инвестициях в малый бизнес (the Small Business Investment Act). Указанный акт был принят для того, чтобы компании малого бизнеса имели возможности для роста и доступа к капиталу, не прибегая к услугам банков и иных частных источников.

Минимальный размер капитала, необходимый для учреждения КИМБ, - 5 млн долл. должен быть предоставлен квалифицированными частными инвесторами. Оставшийся (добавочный) капитал КИМБ в троекратном размере поступает от частного капитала и предоставляется АМБ посредством продажи гарантированных АМБ ценных бумаг.

С момента учреждения в 1958 году программой КИМБ было распределено 46 млрд долл. займов и инвестиций в акционерный капитал в более чем 99000 малых американских предприятий с инвестициями в размере 2,9 млрд долл. в 2005 году.

Многие широко известные компании получили инвестиции КИМБ на ранней стадии своего развития, включая Intel, Apple Computer, Callaway Golf, JetBlue Airways, Whole Foods Market, Palm Computing и др. Одиннадцать из ТОП-100 компаний последнего рейтинга 500 американских наиболее растущих компаний получили финансирование КИМБ (данные на ноябрь 2005 года).

Малый бизнес, получающий финансирование КИМБ, в 2005 году трудоустроил примерно 218000 работников - в среднем по 95 человек на компанию в момент осуществления инвестиций. КИМБ играют важную роль, особенно в производственном секторе экономики, в процессе восстановления американской экономики после последней рецессии. В 2005 году существовало 418 КИМБ, действовавших в 46 штатах США.

\section{Израиль: Yozma}

Другой из наиболее успешных моделей запуска венчурной индустрии и переориентации экономики на инновационно ориентированную модель является модель Израиля Yozma (что на иврите значит «инициатива»), во многом основанная на интеллектуальном потенциале российских ученых-эмигрантов. Модель предполагала создание государственного венчурного «фонда фондов» и последующее развитие 10 частных 
фондов с участием государства, каждый с капиталом 20 млн долл. или более. Үozma была создана под руководством министерства промышленности и торговли Израиля.

К фондам предъявлялись требования наличия хотя бы одного израильского партнера и одного американского или европейского партнера с опытом и репутацией в области венчурного инвестирования (см. табл. 1). При этом зарубежные коллеги обязывались обучать израильских специалистов, в то же время управление фондом должна была осуществлять израильская частная компания.

Создаваемый фонд, прошедший конкурс, получал 8 млн долл. из фонда Yozma (до 40\% от общего размера фонда). В случае успеха фонда была предусмотрена возможность выкупа доли государства по первоначальной стоимости инвестиции плюс небольшой доход при низкой процентной ставке.

В рамках программы фонда Үozma было создано 10 венчурных фондов (см. рис. 2). Наряду с этим существовал полностью государственный фонд — Yozma 1 Fund - объемом 20 млн долл., напрямую инвестировавший в компании на ранних стадиях развития (стартапы) и действовавший с 1993 года; в 1997 году он был приватизирован. Шесть фондов были сформированы в 1993 году, в том числе Gemini, Star, Concord, Pitango, Walden \& Inventec; один в 1994 году — JVP; два в 1995 году — Medica \& EuroFund; и один в 1997 году - Vertex.

Ниже приведены существенные условия программы Yozma (табл. 1).

Таблица 1. Критические параметры программы Yоzma

Предпочтительный тип венчурных компаний (ограниченные партнерства, фонды закрытого типа): девять фондов приняли эти организационные формы, и лишь один был открытым венчурным фондом

Ориентация на инвестиции на ранней стадии в израильские высокотехнологичные cmapmanbl

Целевой уровень капитала - 200-250 млн долл. (государственная поддерэкка 100 млн долл.); это была критическая масса, необходимая для возникновения венчурной индустрии

Многообразие частных израильских венчурных фондов (10), каждый из которых находился под управлением локальной управляющей компании и включал по крайней мере один иностранный финансовый институт с высокой репутацией (и один ваэснейший израильский финансовый институт)

Государственное участие в каждом фонде -8 млн долл. (в больиинстве фондов программы Уоzта оно составляло 40\% от общего объема фонда - 20 млн долл.)

Государственный фонд объемом 20 млн долл. осуществлял инвестиции напрямую в высокотехнологичные компании в Израиле: Этот венчурный капитал назывался "Үоzта - венчурный фонд» (его не следует путать с программой Үозта). Активная инвестиционная политика фонда стимулировала инвестиции венчурных фондов, созданных по программе Yozma

Действенные стимуль к «Потенциалу роста»- возможность в течение 5 лет покупки государственных акций приблизительно по первоначальной стоимости (все фонды, кроме трех, использовали этот опцион). Не было гарантии минимизации рисков

Запланированная «приватизация" фонда "Үозта - венчурный фонд» была осуществлена в 1997 году. Тем самым был подтвержден каталитический эффект программы Yozma

Программа Уоzта послужила началом сильного процесса коллективного обучения

Конечными результатами реализации программы Yozma стал резкий рост инновационной активности в Израиле и расширение экспорта высокотехнологичной продукции. Общее число ежегодно создаваемых в Израиле компаний, использующих новые

Выпуск \#2(6), 2008

(C) Электронный журнал Корпоративные Финансы, 2008 
технологии, выросло с 300 в 1993 году до 2000 к 2005-му. Объем высокотехнологичного экспорта увеличился с 2,2 млрд долл. в 1991 году до 11 млрд в 2000-м.

Eurofund
Gemini
Inventech
JVP
Medica
Nitzanim-Concord
Polaris
Star
Vertex
Walden

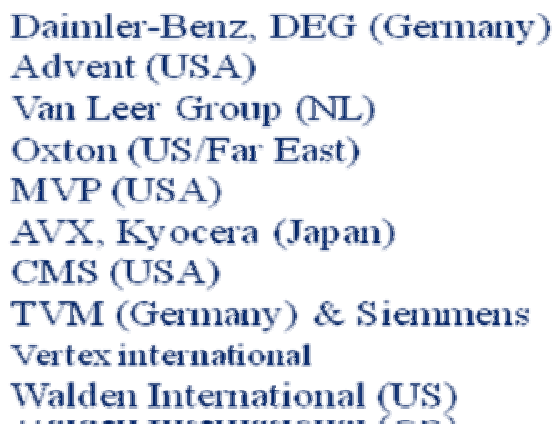

Рис. 2. Венчурные фонды Yоzта и их главные зарубежные инвесторы

Yozma имела большой успех. В течение первого года было сформировано шесть, а за три года - все десять фондов с зарубежными партнерами. Общие чистые инвестиции в них составили 250-256 млн долл., из которых 80-100 млн долл. было профинансировано Yozma, и они проинвестировали более 200 инновационных компаний [Avnimelech G., Teubal V., 2002]. В дальнейшем капитал дочерних фондов Yozma возрос до 2,9 млрд долл. за счет привлечения новых инвесторов и успешных продаж портфельных компаний, а восемь из десяти фондов были выкуплены частными соучредителями. Число технологических компаний в стране превысило 4000. Израиль был успешно включен в мировой технологический бизнес.

Благодаря реализации проекта Yozma на сегодняшний день Израиль имеет общепризнанные прочные позиции на мировом рынке венчурного капитала. Ежегодно в Израиле объем сделок в высокотехнологичные компании достигает 1,2 млрд долл. в год (рис.3).

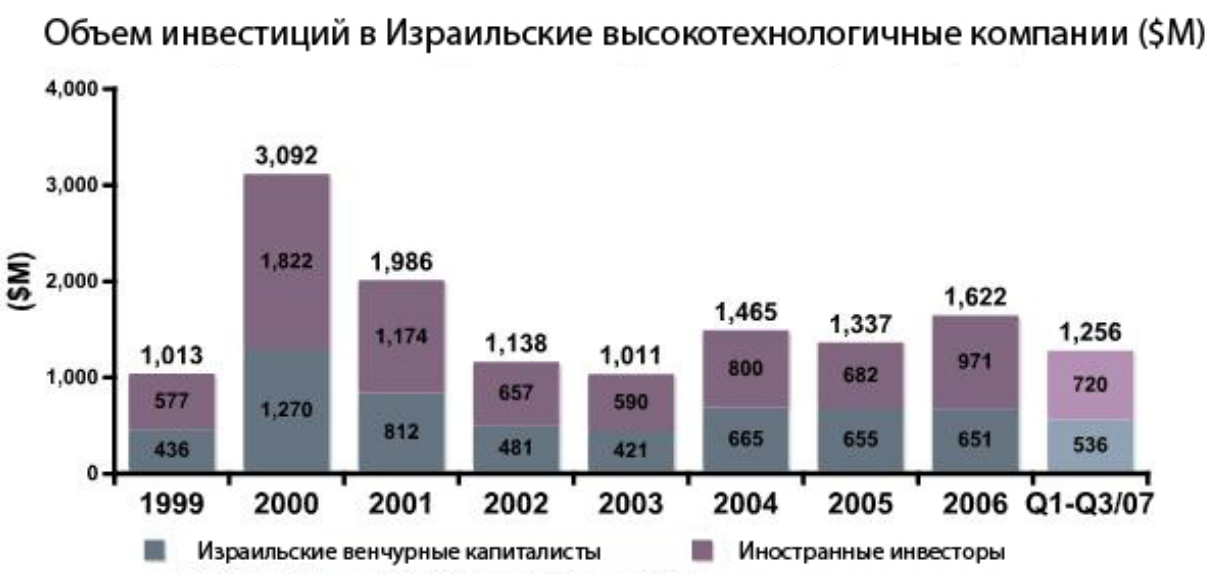

: IVC Research Center

\section{Рис. 3. Объем венчурных инвестиций в Израиле}

\section{Финляндия: SITRA}

В Финляндии также была выстроена одна из самых эффективных в мире систем венчурного финансирования, основой которой стал Национальный фонд исследований и развития Финляндии (SITRA, рис.4). Фонд был создан в 1967 году государством и в настоящий момент регулируется парламентом Финляндии. Одной из его целей является поддержка инновационных компаний в Финляндии и других странах, в том числе посредством прямых инвестиций и инвестиций через венчурные фонды. Эта модель существенно отличается от модели, сложившейся в США. Главной составляющей финского успеха стало оптимальное взаимодействие государства, науки и частного бизнеса на основе выработки общих правил и согласования интересов.

Выпуск \#2(6), 2008 () Электронный журнал Корпоративные Финансы, 2008 


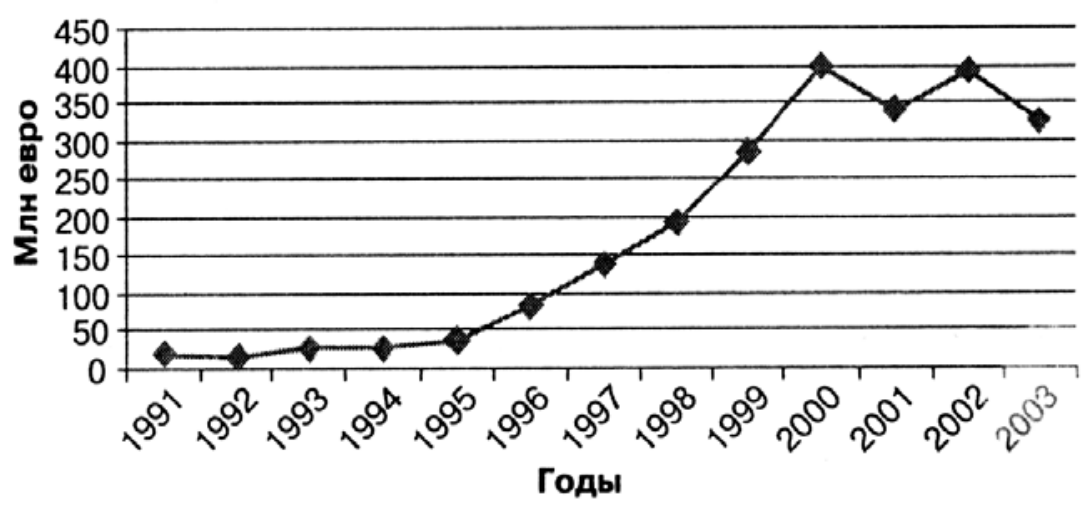

Рис. 4. Объем прямых и венчурных инвестиций в Финляндии. Катализатором развития венчурных инвестиций стал фонд «посевных» инвестиций SITRA. Средний объем инвестиций - 30 млн евро в год

Источник: Finnish Venture Capital Association.

\section{Китай}

Структура отрасли венчурных инвестиций в Китае во многом уникальна и не имеет аналогов в других развитых и развивающихся странах. Несмотря на то что с момента образования в Китае первого венчурного фонда прошло менее 20 лет, развитие венчурного бизнеса в этой стране впечатляет: по данным на 2002 год, в Китае насчитывается около 86 тысяч высокотехнологических предприятий, на которых трудилось около 5,6 млн работников, совокупная выручка которых составила около 180 млрд долл.

Начало развития инфраструктуры венчурного бизнеса было положено в 1978 году программой «Четырех модернизаций»; в 1979 году последовала легализация иностранной инвестиционной деятельности на территории КНР, а в 1984 году были дополнительно открыты еще 14 специальных экономических зон. В 1992 году местными органами управления в Shenyang, Shanxi, Guangdong, Shanghai, Zhejiang создаются венчурные корпорации развития технологий. Однако к середине 1990-х существовавшая тогда система проявила свою неэффективность. Исследователи Школы экономики и менеджмента Университета Цинхуа (Tsinghua University) выделяют две причины этого: во-первых, это недостаток финансовых ресурсов; и во-вторых - отсутствие эффективной системы конкурсного отбора перспективных проектов. Венчурных фондов, работающих на коммерческих основах, тогда не существовало.

B 1996 году был принят закон, разрешающий создание таких венчурных фондов (Law Promoting the Industrialization of China's Technological Achievements). В этом же году китайское правительство создает свыше 20 государственных венчурных фондов, финансируемых местным правительством, и отправляет в США делегацию с целью изучения опыта организации венчурных инвестиций. Уже в следующем, 1997 году на рынке венчурных инвестиций появились первые иностранные игроки. Первыми инвестициями этих фондов стали вложения 18 млн долл. в технологическую компанию AsiaInfo и 6,5 млн долл. в первую китайскую венчурную ИТ-компанию, предшественника Sohu.com. В последующие годы был принят ряд законов, облегчающих создание коммерческих и иностранных венчурных фондов в Китае [Пеникас Г., Маленко А., Высшая школа экономики, 2005].

Как уже упоминалось, особенностью Китая была определяющая роль государства в формировании отрасли венчурных инвестиций. Выделим три направления, по которым государство воздействовало на развитие отрасли:

1) децентрализация управления;

2) предоставление непосредственной финансовой поддержки венчурным проектам; 
3) создание институциональной среды для развития венчурного бизнеса.

Главным источником финансовых ресурсов для венчурного предпринимателя выступают венчурные фонды - специализированные предприятия, предоставляющие на определенных условиях финансовые ресурсы для венчурных компаний и направленные, как правило, на извлечение прибыли. Все венчурные фонды, оперирующие в Китае, можно подразделить на четыре типа:

- государственные венчурные фонды;

- университетские венчурные фонды;

- корпоративные венчурные фонды;

- иностранные венчурные фонды.

Первый венчурный фонд, созданный в Китае министерством финансов совместно с Комиссией по науке и технологии в 1985 году, был государственным. Впоследствии, в первой половине 1990-х годов, роль и число государственных венчурных фондов заметно возросли, хотя подавляющее большинство из них, в отличие от первого фонда, создавались органами местного самоуправления. Данные фонды, как правило, испытывают дефицит квалифицированных управленческих кадров и ориентированы на прибыль в меньшей степени, чем фонды других типов. Хотя формально все фонды данного типа являются коммерчески ориентированными, местные правительства зачастую волнуют цели, отличные от достижения приемлемой отдачи от инвестиций. Все это приводит к тому, что последние несколько лет доля государственных фондов в общем объеме венчурных инвестиций в Китае постоянно сокращается.

Венчурные фонды, созданные при университетах и научно-исследовательских институтах, в значительном количестве стали появляться начиная с 2000 года. Они имеют уникальную возможность взаимодействия и сотрудничества с научной элитой - научными работниками, работающими в университетах и НИИ. Именно эта возможность обеспечила успех таким фондам уже на начальной стадии их появления. Однако для этих фондов были характерны те же проблемы, что и для государственных венчурных фондов; главная из них - недостаток финансовых ресурсов. Возможным решением этой проблемы является сотрудничество фондов при университетах и НИИ с корпоративными и иностранными венчурными фондами в реализации совместных проектов на основе софинансирования.

Корпоративные фонды на сегодняшний день представляют большинство венчурных фондов, оперирующих в Китае. К 2002 году 132 публичных компании, или 11\% от общего объема зарегистрированных на бирже корпораций, инвестировали в такие венчурные фонды. Корпоративные фонды, как правило, имеют солидную финансовую базу, поддержку государства и более квалифицированные управленческие кадры, чем государственные и университетские венчурные фонды. Это позволяет фондам инвестировать крупные ресурсы в коммерчески выигрышные проекты. С другой стороны, корпоративные фонды не готовы инвестировать в особо рисковые и долгосрочные проекты по причине необходимости демонстрировать высокие ежегодные финансовые показатели.

Наравне с корпоративными венчурными фондами иностранные венчурные фонды стали с момента своего появления основным источником венчурных инвестиций в Китае. К концу 2001 года 8 из 10 и 14 из 20 крупнейших венчурных фондов, оперирующих в Китае, были иностранными. Важнейшими достоинствами иностранных венчурных фондов являются солидная финансовая база, наличие квалифицированных менеджеров с большим опытом работы в венчурном финансировании и готовность брать на себя высокие риски и инвестировать в долгосрочные проекты. Недостаток знаний специфики ведения бизнеса в Китае отчасти компенсируется наличием китайских управляющих среди топ-менеджмента большинства иностранных венчурных фондов.

При условии сохранения открытости экономики Китая для зарубежных инвесторов можно прогнозировать рост значимости иностранных венчурных фондов на рынке венчурных инвестиций страны. Так, Intel объявила 8 апреля 2008 года о создании венчурного фонда Intel Capital China Technology Fund II размером 500 млн долл.. 


\section{Обобщение практики и рекомендации Организации Объединенных Наций по построению индустрии венчурного финансирования}

Ниже приведены несколько рекомендаций ООН, основанных на лучших практиках европейских и других стран и фактически задающих некие правила создания эффективной национальной венчурной индустрии:

В некоторых странах (в Канаде, Дании, Финляндии, Норвегии, Португалии, Испании, Швеции) средства для инвестиций передаются в специальные учреждения, как правило, аффилированные с организациями, занимающимися развитием бизнеса или промышленности, с требованием осуществления прямых инвестиций в новые, малые или инновационные предприятия. Фонды, находящиеся в государственном управлении, могут стать важным первоначальным источником капитала, который мог бы содействовать накоплению инвестиционного опыта и постепенной передаче его в частный сектор. Фонды, специализирующиеся на высокорисковых инвестициях в компании ранней стадии развития, подходят для реализации этой задачи лучше всего.

Когда рыночные механизмы только начинают формироваться, государственные фонды лучше всего использовать в качестве дополнительного элемента и поддержки. В этом отношении программы, задействующие государственные фонды, начали все больше привлекать менеджеров, ранее занимающихся частными инвестициями, - или смещать акцент их деятельности к инвестированию из государственных «фондов фондов» в частные закрытые фонды (Канада, Дания, Финляндия, Норвегия).

Еще одним подходом к обеспечению государственного финансирования венчурных инвестиций стали случаи привлечения менеджеров, занимающихся частными инвестициями, или дополнительных частных средств. Типичный сценарий использования этого подхода выглядит следующим образом: правительство или правительственное учреждение выступает в качестве основного инвестора, предоставляя определенный процент капитала фонда. Такой подход в настоящее время стал особенно популярен в ряде стран: в Канаде, Дании, Финляндии, Франции, Германии, Ирландии, Израиле, Великобритании, США и (недавно) Казахстане, Латвии и России, а также в Европейском инвестиционном фонде. В рамках такого подхода правительство инвестирует как непосредственно в акционерный капитал, так и в субординированные займы.

Опыт реализации программы SBIC в США является наглядным доказательством востребованности структур, стимулирующих инвестиции в компании ранней стадии развития. На начальном этапее реализации этой программы необходимость обслуживания займов, предоставленных SBA участвующим инвестиционным компаниям, делала инвестиции в предприятия, неспособные обеспечивать поступление кассовой наличности, нецелесообразными. Переход от займов к участвующим привилегированным ценным бумагам с отложенной выплатой процентов на ранней стадии в обмен на последующее участие в прибыли явил собой значительное продвижение к посевным инвестициям.

Израильская программа Үоzта представляет собой еще один пример методов стимулирования потенциала роста венчурных фондов: каждый фонд получал опцион на покупку правительственных паев на период до 5 лет, начиная с момента основания фонда. Подобным образом недавно запущенные программы в Великобритании («Энтерпрайз Кэпитал Фандз»), Латвии («Латвийское агентство по гарантированию инвестиций») и России («Российская венчурная компания») ограничивают доходность правительственных паев, передавая фактически весь излишек инвестиционным менеджерам и ограниченным партнерам. Такие соглашения обеспечивают асимметричное распределение дохода от успешных инвестиций, делая их более соизмеримыми с высокими рисками инвестирования в компании на ранней стадии развития [United Nations, Economic Commission for Europe, 2007]. 
Таким образом, можно сделать вывод, что практика использования различных механизмов и институтов действует практически по всей Европе, и наша страна не может не учитывать достижения этой практики для определения уникальной российской модели.

Наряду с рекомендациями в отношении деталей различных моделей важное значение имеют и общие правила построения государственной политики в области создания института венчурного финансирования:

1. Цели политики, связанные с финансированием инноваций, должны быть реалистичны, они должны принимать во внимание преобладающие фоновые условия в отношении четырех стадий цикла финансирования инновационных разработок и учитывать связи между различными факторами спроса и предложения.

2. Цели политики должны быть конкретны: необходимо конкретно указывать типы предприятий, которые должны получить поддержку: инновационные, вновь созданные (стартапы), на стадии роста, успешные и т. д. Каждый тип предприятий предполагает разные перспективы привлечения частных инвесторов.

3. Изучение опыта других стран и, следовательно, реализация программ, успешно осуществленных в этих странах, зависит от того, четко ли инвесторы понимают, в чем заключались действия, предпринятые в прошлом, и в чем заключается историческое наследие инновационных возможностей и развития рынка.

4. Государственные программы показывают наилучшие результаты тогда, когда они являются вспомогательным элементом, содействующим рыночным механизмам, связанным с финансированием инновационных разработок. Правительствам лучше всего удается формировать параметры, в рамках которых частные инвесторы принимают решения посредством предоставления соответствующих стимулов, - чем принимать решения самим.

Решения правительств о прямом инвестировании бюджетных средств должны приниматься децентрализовано, с привлечением учреждений, тесно связанных с объектами инвестиций, и предпочтительно в отношении проектов на самой ранней стадии развития.

\section{Российская модель создания венчурной индустрии}

Переход России на инновационный путь развития потребовал формирования в стране института венчурного финансирования. Инвестиционные механизмы в области венчурного предпринимательства в России все еще остаются слабыми, особенно в части комплексных стимулирующих мер, способствующих развитию венчурного бизнеса и снижению венчурных рисков. В настоящее время российские высокотехнологичные инновационные компании, находящиеся на ранней фазе, не вызывают интереса у профессиональных венчурных инвесторов. Не получая финансовой поддержки, новые инновационные проекты не начинаются вовсе или закрываются. Рынок венчурных инвестиций в России находится на этапе становления и требует государственного участия для создания модели венчурного финансирования и комплексного развития венчурной индустрии (ис. 5,6$)$. Важной задачей является определение путей государственного участия в становлении венчурного инвестирования, а также определение роли частного бизнеса в развитии венчурной индустрии. 


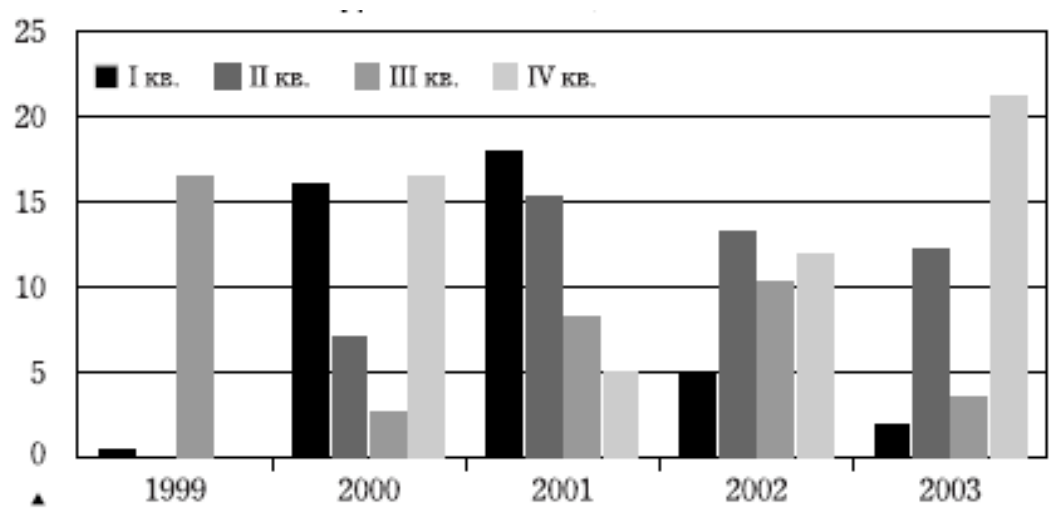

мтн долл

Рис. 5. Венчурные инвестиции в России в 1999-2003 годах, млн долл. [Аммосов Ю. П., 2005]

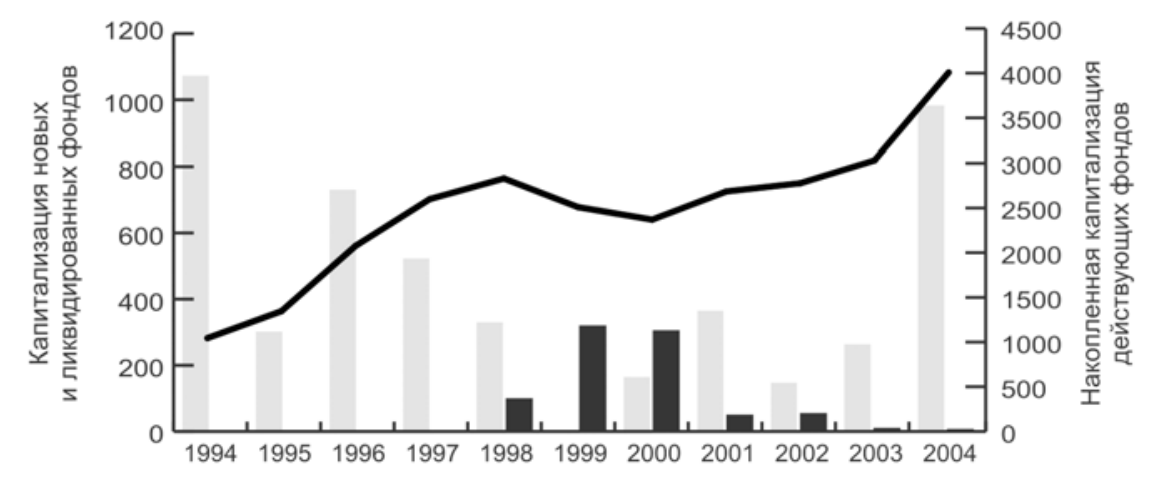

Рис. 6. Капитализация венчурных фондов и фондов прямых инвестиций в России в 1994-2004 годах, млн долл. [Гладких И., 2006]. Объем венчурных инвестиций составляет $\sim 15-20 \%$

В Послании Президента Российской Федерации Федеральному Собранию в 2006 году В. В. Путин определил инновационное направление развития: «В условиях жесткой международной конкуренции экономическое развитие страны должно определяться главным образом её научными и технологическими преимуществами... Нам надо сделать серьезный шаг к стимулированию роста инвестиций в производственную инфраструктуру и в развитие инноваций... Нам в целом нужна сегодня такая инновационная среда, которая поставит производство новых знаний «на поток» [Путин В.В., 2006]. 


\section{Таблица 2. Прямые и венчурные инвестиции по отношению к ВВП}

\section{Обзор мировых показателей прямых и венчурных инвестиций}

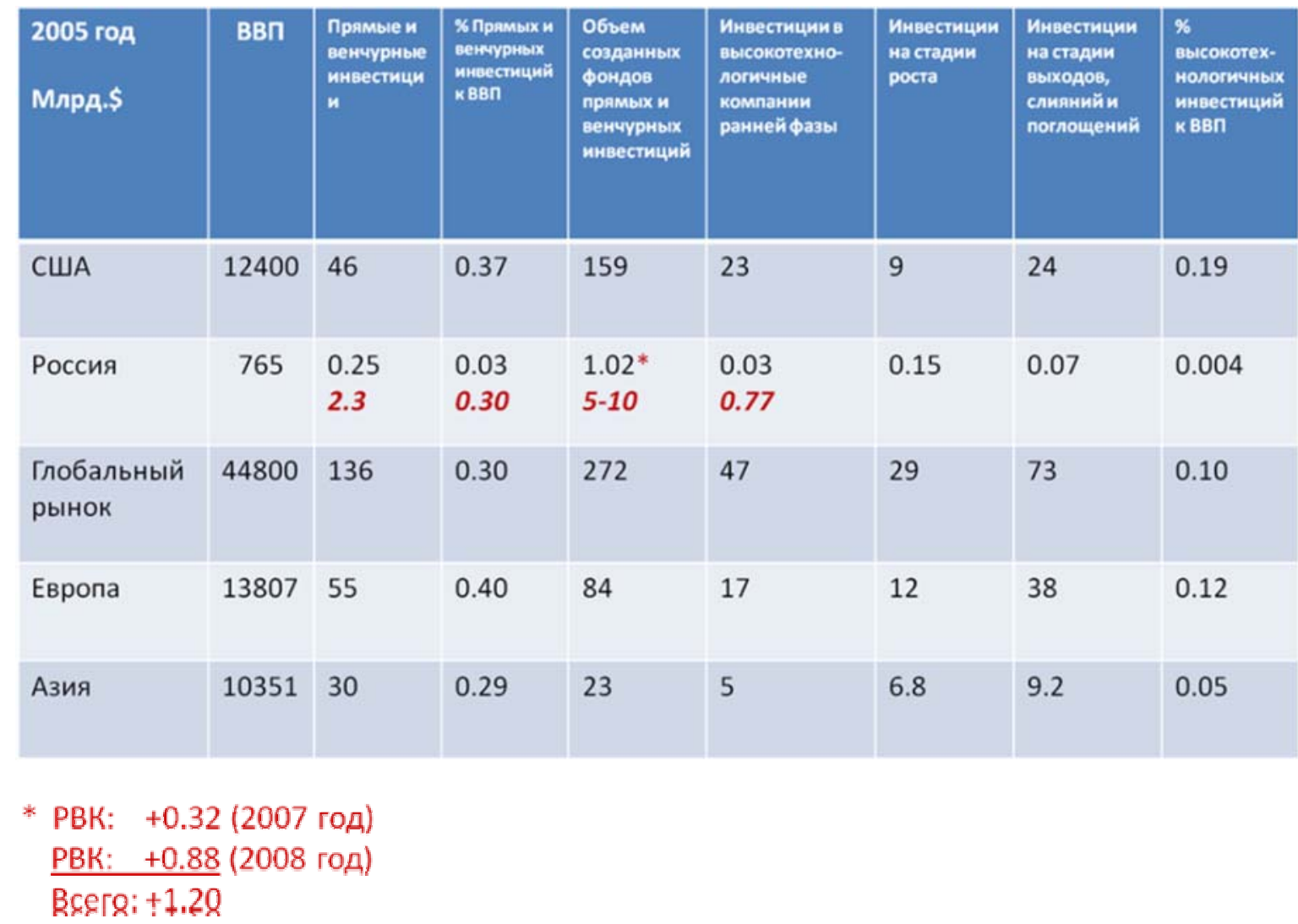

Из таблицы 2 можно сделать вывод, что по мировым показателям объем прямых и венчурных инвестиций составляет всего 0,3\% ВВП страны (показатели 2005 года). Таким образом, потенциал роста объема прямых и венчурных инвестиций России составляет до 2 млрд долл. в год. Объем же формирования фондов прямых и венчурных инвестиций имеет потенциал 5 млрд долл. в год. Значительное участие государства в создании венчурных фондов как фондов с участием ОАО «Российская венчурная компания» (1,2 млрд долл.), так и в создании более 20 региональных венчурных фондов должно стать сигналом рынку и обеспечить дополнительный эффект катализатора развития рынка.

\section{Создание института развития венчурной индустрии}

Правительством Российской Федерации (Распоряжение № 838-р от 7 июня 2006 года) учреждено ОАО «Российская венчурная компания» (ОАО «РВК») с целью стимулирования создания в России собственной индустрии венчурного инвестирования, развития инновационных отраслей экономики и продвижения на международный рынок российских наукоемких технологических продуктов [Сводный план, 2006]. На российскую венчурную компанию возложены две основные функции: отбор лучших венчурных управляющих компаний на конкурсной основе и приобретение паев венчурных фондов, создаваемых этими компаниями.

Текущая капитализация ОАО «РВК» составляет 30 млрд руб. - в соответствии с Постановлением Правительства Российской Федерации от 24 августа 2006 года № 516 и Распоряжением Правительства Российской Федерации от 29 ноября 2007 года №1694-р.

9 июня 2007 года первый вице-премьер РФ Сергей Иванов, выступая на ХI Петербургском экономическом форуме, сообщил, что с участием Российской венчурной 
компании будет создано 8-12 венчурных фондов с совокупным капиталом порядка 30 млрд руб. Он напомнил, что первые венчурные фонды, созданные с участием РВК, начнут работу уже в конце лета — начале осени 2007 года. По словам С. Иванова, венчурные фонды обеспечат венчурным капиталом до 200 инновационных компаний и станут косвенным катализатором создания еще порядка 1000 предприятий [РосБизнесКонсалтинг, 2007].

\section{Итоги первого года работы нового института развития российской модели}

К основным достижениям 2007 года на пути построения инновационной системы можно отнести следующие результаты инвестиционной деятельности ОАО «Российская венчурная компания»: 1 марта 2007 года был объявлен первый конкурсный отбор с предельной суммой 4,8 млрд руб. По итогам конкурсного отбора среди 13 управляющих компаний были объявлены 3 победителя. Общий спрос на инвестиционные ресурсы составил более 26 млрд руб. Столь высокий интерес частного сектора к программе развития новой индустрии оказался неожиданным даже для председателя совета директоров ОАО «Российская венчурная компания» Германа Грефа: «Вместо ожидаемых трех-четырех заявок от участников рынка поступило 13. Мы ошиблись в прогнозах минимум вдвое» [РБК daily, 2007].

В 2007 году создано два венчурных фонда с общей капитализацией 6,061 млрд руб.:

1. ЗПИФ ВИ «ВТБ-Фонд венчурный» с капитализацией 3,061 млрд руб.

2. ЗПИФ ВИ «Биопроцесс Кэпитал Партнерс» с капитализацией 3 млрд руб.

Модель российской венчурной компании построена на механизме частногосударственного партнерства - размер инвестиций в отдельный венчурный фонд в обмен на $49 \%$ от общего числа инвестиционных паев: от 600 млн руб. до 1,5 млрд руб. Остальные $51 \%$ общего объема создаваемых венчурных фондов должны привлечь компании, признанные победителями конкурсного отбора, в том числе не менее 1\% этих средств должны приобрести венчурные специалисты этих управляющих компаний. Венчурные фонды могут приобретать только ценные бумаги российских инновационных компаний, находящихся на ранней фазе развития, - не менее $80 \%$ от общего объема инвестируемых средств фонда. Направления инвестирования создаваемых с участием РВК венчурных фондов ограничены областями приоритетных направлений развития науки, технологий и техники Российской Федерации и списком критических технологий, утвержденных Президентом Российской Федерации.

Для реализации механизма инвестиций в 2007 году была выбрана единственно доступная в законодательстве форма закрытого паевого инвестиционного фонда (ЗПИФ). Несомненным плюсом указанной формы является наличие: правовой базы ${ }^{25}$, государственного регулятора ФСФР, инфраструктуры (аудитор, оценщик, специализированный депозитарий), опыта работы на рынке профессиональных управляющих компаний, лицензированных и контролируемых государственным регулятором, которым доверяются средства инвестора. Отсутствует текущее налогообложение инвестиций, так как ЗПИФ не является юридическим лицом, а представляет собой имущественный комплекс. Минусом указанной системы явилось то, что правила создания ЗПИФ обязывают пайщиков (частных инвесторов и РВК) выкупить паи в полном объеме в течение 1 месяца с начала формирования фонда. После формирования фонда деньги поступают на счета специализированного депозитария в банках, а управляющая компания начинает формировать сделки по приобретению пакетов инвестиционных компаний.

Вместе с тем мировая практика показывает, что зарубежные венчурные фонды наполняются живыми деньгами не сразу, как предусматривает форма ЗПИФ, а по

\footnotetext{
${ }^{25}$ Федеральный закон № 156-ФЗ от 29.11.2001 «Об инвестиционных фондах» (в ред. Федеральных законов от 29.06.2004 № 58-Ф3, от 15.04.2006 № 51-Ф3), Постановление Правительства РФ № 564 от 25 июля 2002 «О типовых правилах доверительного управления закрытым паевым инвестиционным фондом».
} 
необходимости, в момент совершения сделок. До этого момента пайщики предоставляют commitment letter, то есть финансовые гарантии. Второй существенный минус - это зафиксированный в законе об инвестиционных фондах исчерпывающий перечень прав инвестора (пайщика). В соответствии с этим законом, пайщик не принимает участия в процессе управления фондом и не контролирует процесс формирования портфеля фонда.

Мировая практика также использует институт инвестиционных комитетов, которые наделены юридическим правом вето на совершение сделок управляющей компанией. В соответствии с российским законодательством, контроль за сделками ведёт специализированный депозитарий, который является агентом ФСФР и не зависит от управляющей компании и пайщиков.

В состав членов совета директоров ОАО «Российская венчурная компания» входят как высокопоставленные чиновники, отвечающие за развитие инновационного сектора экономики, так и профессиональные венчурные капиталисты с мировым именем. В российской венчурной компании действует институт независимых членов совета директоров: Игаль Эрлих — председатель и управляющий партнер венчурной группы Yozma, Израиль; Эско Ахо - президент Государственного фонда развития инновационной деятельности SITRA, Финляндия; Константин Вадимович Ремчуков - издатель «Независимой газеты»; Алексей Валерьевич Коробов (генеральный директор Российской венчурной компании). В 2007 году интересы государства в совете директоров представляли: Герман Оскарович Греф - председатель совета директоров, Игорь Юрьевич Артемьев - руководитель Федеральной антимонопольной службы России, Дмитрий Викторович Ливанов - ректор МИСиС. В 2008 году интересы государства в совете директоров представляют: председатель совета директоров Эльвира Сахипзадовна Набиуллина - министр экономического развития и торговли Российской Федерации, Андрей Александрович Фурсенко - министр образования и науки Российской Федерации, Игорь Юрьевич Артемьев — руководитель Федеральной антимонопольной службы России.

\section{Соотношение риск-доходность в рамках российской модели}

В России риск, связанный с венчурными инвестициями, выше ожидаемой доходности от них. Государственное вмешательство призвано изменить соотношение риск-доходность для частных инвесторов, чтобы стимулировать приток частных инвестиций. В соответствии с прогнозом Минэкономразвития РФ, уровень инфляции должен снизиться до $5 \%$ годовых. Ограничение доходности ОАО «РВК» путем предоставления возможности инвесторам права выкупа принадлежащих ОАО «РВК» инвестиционных паев венчурного фонда - 5\% годовых, но не выше среднегодового уровня инфляции, что обеспечивает дополнительный доход инвесторам. ОАО «РВК» (и в ее лице государство) и частные инвесторы в одинаковой степени разделяют инвестиционные и финансовые риски. Это делает привлекательным для инвесторов соотношение риск-доходность (рис 7). Доходность ОАО «РВК» складывается из доходностей 8-12 венчурных фондов, финансовая стабильность достигается за счет диверсификации. 


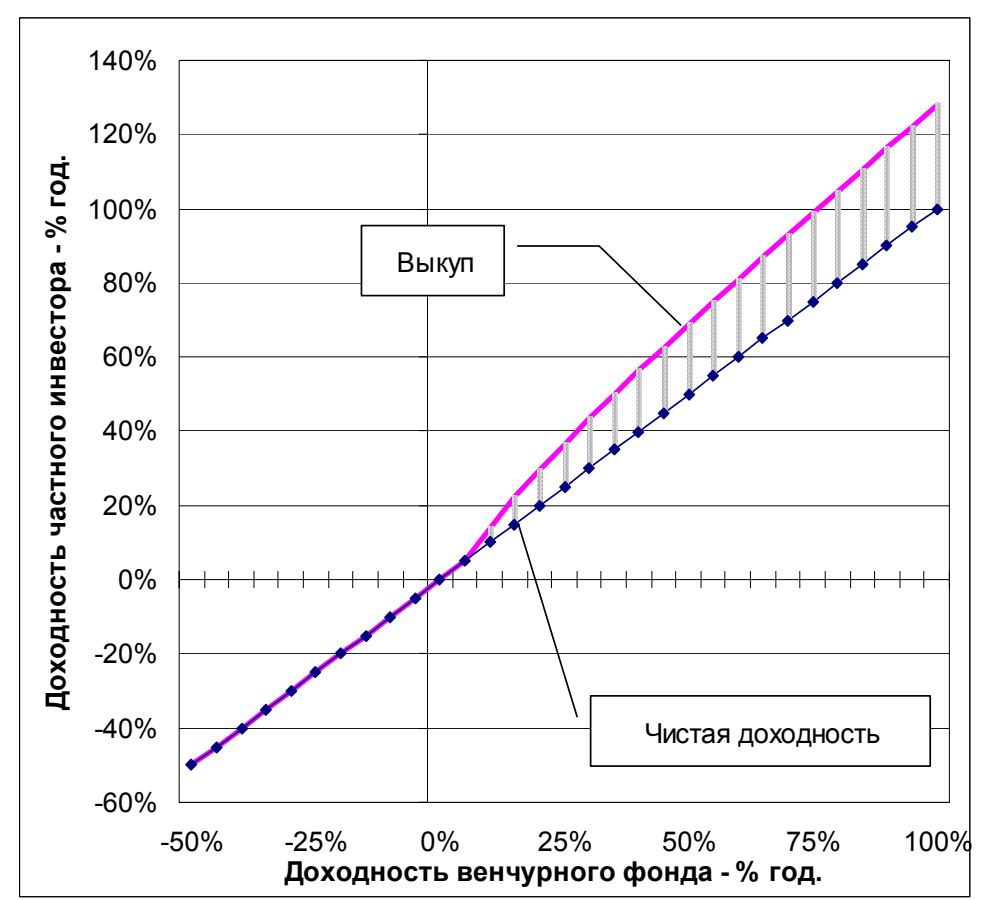

Рис. 7. Ограничение доходности РВК. Исходные посылки для расчета: доля частного инвестора - 51\%, РВК - 49\%, процентная ставка РВК - 5\% годовых, срок исчисления доходности - 5 лет. Ромбовидный пунктир - исходная доходность венчурного фонда или же доходность инвестора без участия государства; светлая линия - доходность при схеме выкупа

\section{Инвестиционная деятельность венчурных фондов с участием ОАО «РВК»}

В фондах, сформированных с участием ОАО «РВК», наблюдается высокая динамика инвестиционного процесса, значительно превышающая показатели традиционных венчурных фондов.

Инвестиционный комитет «ВТБ - Фонд венчурный» рассмотрел пул из 12 инвестиционных проектов с общим объемом требуемых инвестиций 2134 млн руб. что составляет 70\% от общей капитализации фонда. Проведен первый раунд финансирования семи инвестиционных проектов на общую сумму в 784 млн руб., что составляет 37\% от общей суммы всех проектов, одобренных для финансирования, и $26 \%$ от общей капитализации фонда. Инвестиции в остальные проекты, одобренные Инвестиционным комитетом «ВТБ - Фонд венчурный», планируется осуществить во II-IV кварталах 2008 года (рис. 8). 


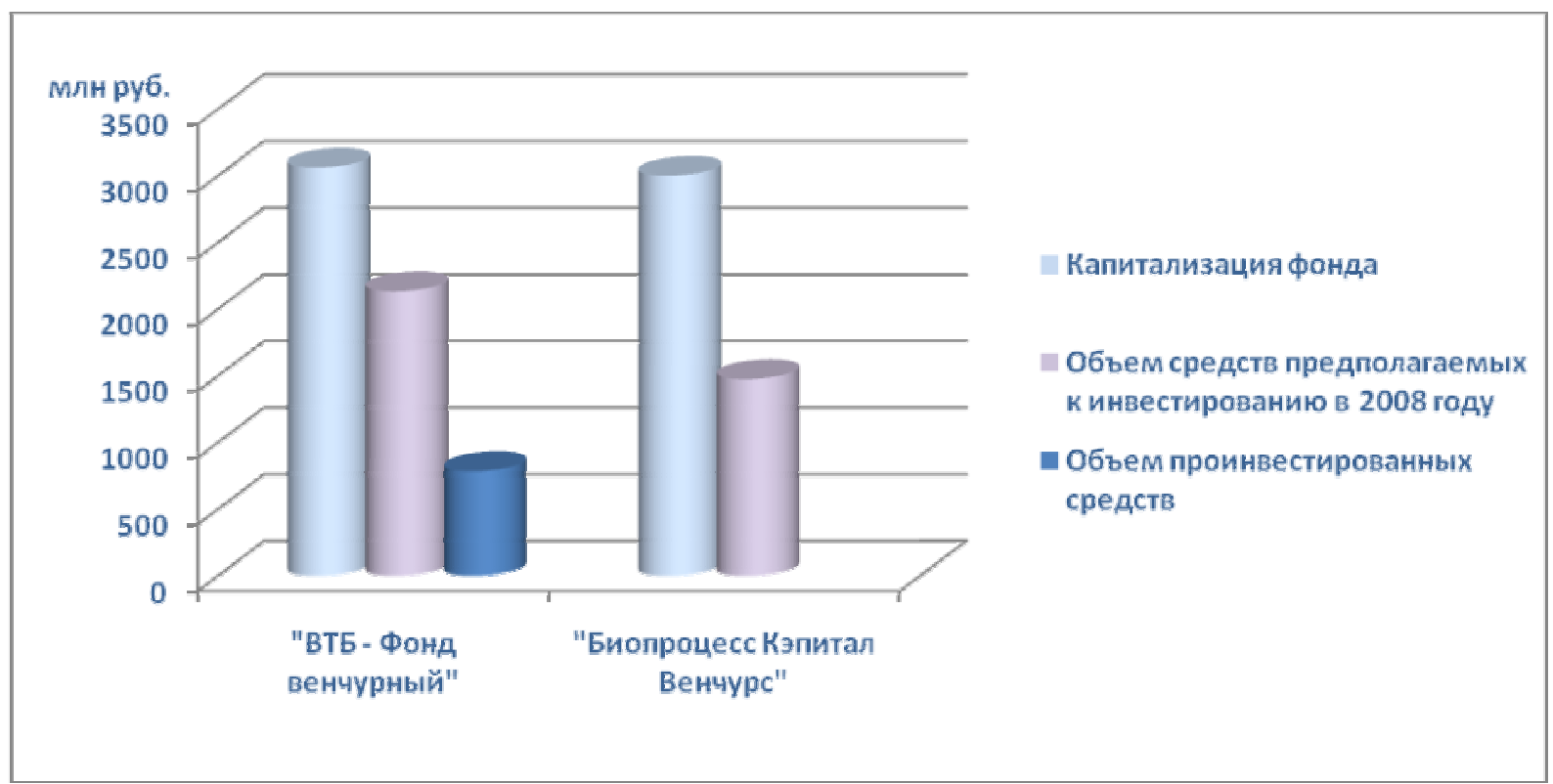

\section{Рис. 8. Динамика инвестиционного процесса}

Инвестиционный портфель «ВТБ - Фонд венчурный» распределен между областями приоритетных направлений развития науки, технологий и техники Российской Федерации в следующих пропорциях:

1. Информационно-телекоммуникационные системы $-37 \%$.

2. Рациональное природопользование $-25 \%$.

3. Энергетика и энергосбережение $-19 \%$.

4. Транспортные, авиационные и космические системы $-10 \%$.

5. Технологии обработки, хранения, передачи и защиты информации $-6 \%$.

6. Технологии производства программного обеспечения $-3 \%$.

По приоритетным направлениям инвестиций можно выделить лидирующие сегменты это информационно-телекоммуникационные системы и рациональное природопользование, инвестиции в которые по отношению к общему объему сделок, одобренных инвестиционным комитетом «ВТБ - Фонд Венчурный», составляют 37 и 25\% соответственно (рис. 9).

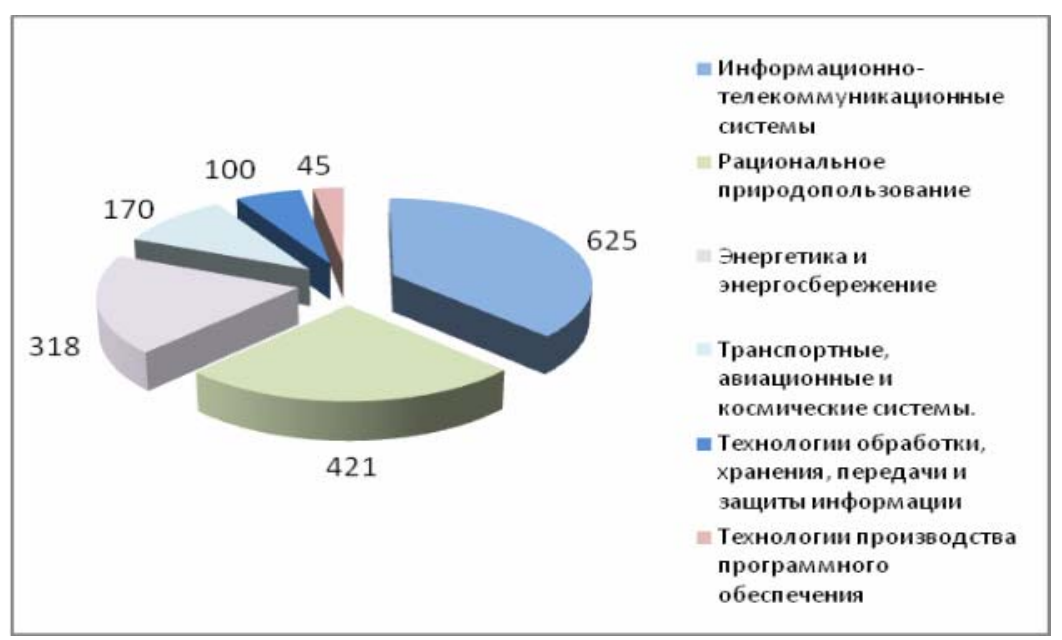

Рис. 9. Сегментация по направлениям инвестиций

В планах фонда «Биопроцесс Кэпитал Венчурс» - рассмотреть вопрос финансирования инновационных проектов на общую сумму 1475 млн руб. В 2008 году планируется рассмотреть на инвестиционном комитете пул проектов на сумму, 
составляющую более 49\% от объема венчурного фонда [руглый стол ОАО «РВК», 25.03.2008].

Важным аспектом является расширение компетенций управляющей компании по увеличению стоимости портфельных компаний за счет привлечения иностранных специалистов и интеграции российских инновационных компаний в мировой рынок.

Высокие темпы инвестиций, с одной стороны, можно объяснить высоким спросом на инвестиционные ресурсы российских инновационных компаний; а с другой - тем, что высокие темпы инвестиций оправданны с точки зрения доходности фонда. Существующие фонды при сформировании полностью наполнены денежными средствами и, как следствие, заинтересованы в ускоренном размещении средств в компании, так как иначе они имеют право размещать средства только на депозитных счетах, что приносит минимальных доход. Обратная сторона ускоренного инвестиционного процесса состоит в потенциальных рисках, связанных с низким качеством подготовленных сделок. Согласно мировой практике, инвестиционный период занимает от 3 до 5 лет. Можно предположить, что для венчурных фондов с участием российской венчурной компании при такой же интенсивности инвестиций, как на текущий момент, инвестиционный период составит всего 1 год. Таким образом, интенсивность инвестиций российских венчурных фондов — в 3-5 раз выше общемировой практики.

\section{Проведение второго конкурсного отбора управляющих компаний}

В 2008 году планируется проведение двух конкурсов управляющих компаний с общей суммой денежных средств, направляемых на приобретение паев венчурных фондов, создаваемых победителями этих отборов, в размере 12 млрд руб.

Максимальная общая сумма приобретения инвестиционных паев венчурных фондов во втором конкурсном отборе утверждена на заседании совета директоров 7 февраля 2008 года и составляет 9 млрд руб. Второй конкурсный отбор был объявлен 14 марта 2008 года. Российская венчурная компания провела два круглых стола с участниками рынка по разъяснению положений о конкурсном отборе и представлению нововведений по сравнению с первым конкурсным отбором (рис. 10).

\section{Изменения по сравнению с 1-м конкурсным отбором}

\section{По претендентам:}

Допускаются к участию
только управляющие
компании

Допускаются управляющие

компании с уже

существующими

венчурными фондами

\section{По информации:}

единые фиксированные Формы:

-Сведения о венчурных специалистах -Справка о венчурном фонде -Справка по инвестиционным проектам -Шаблон инвестиционногомеморандума

Презентационные материалы предоставляются вместе с заявкой

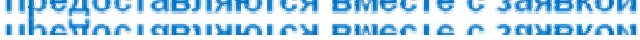

Рис. 10. Изменения по сравнению с первым конкурсным отбором

Претендент предоставляет инвестиционный
меморандум:
-Детализировано содержание иданы
разъяснения по заполнению
-Минимум 6 инвестиционных проектовна
различных стадиях
•Финансовая и организационная модель фонда 
Существенно упростил подготовку конкурсной заявки проект инвестиционного меморандума, разработанный Российской венчурной компанией, в котором даны пояснения по ключевым составляющим содержания заявок и формы заполнения документов. Также по условиям конкурсного отбора управляющие компании обязаны заполнить по фиксированным формам справки на венчурных специалистов, инвестиционные проекты и общую справку о венчурном фонде.

Ниже приведены основные существенные условия конкурсного отбора, которые представляют собой матрицу российской модели (рис. 11, 12) [Круглый стол ОАО «РВК», 04.04.2008].

Существенные условия второго конкурсного отбора

1. Максимальная общая сумма приобретения инвестиционных паев - 9 млрд рублей.

2. Размер инвестиций ОАО "РВК" в отдельный венчурный фонд-минимальный 600 млн рублей, максимальный 1500 млн рублей.

3. Принципы инвестиционной политики ОАО «РВК”:

безоласность и противодействие терроризму, живые системы (в том числе биотехнологии и медицинские технологии и оборудование), индустрия наносистем и материалов, информационно-телекоммуникационные системы, рациональное природопользование, транспортные, авиационные и космические системы, энергетика и энергосбережение.

4. Доля компаний ранней фазы $-\mathbf{8 0} \%$.

5. Конкурсный залог - 20 млн. рублей

6. Предварительное наличие обязательств частных инвесторов $-51 \%$ от общего планируемого числа инвестиционных паев.

7. Специалисты управляющей компании приобретают не менее $1 \%$ от общего планируемого числа инвестиционных паев.

8. Ограничение доходности РВК- $5 \%$ годовых, но не выше среднегодового уровня инфляции.

9. Претендент должен иметь в штате или привлечь по гражданско-правовому договору не менее 3 специалистов в сфере венчурных инвестиций

10.К участию в конкурсном отборе допускаются только управляющие компании.

11.Участниками конкурсного отбора могут быть управляющие компании с уже сформированными ЗПИФ особо рисковых (венчурных) инвестиций.

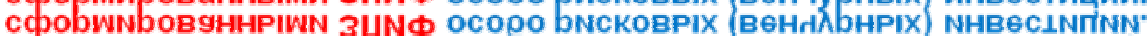

\section{Рис. 11. Существенные условия конкурсного отбора}

Если сравнивать российскую модель с израильской программой Yozma, то в российской модели отсутствует обязательное условие иностранного инвестора, обладающего высокой репутацией и опытом ведения венчурного бизнеса. Однако, несмотря на необязательность, «ВТБ - Фонд венчурный» объявил о партнерских связях с американским фондом Draper Fisher Jurvetson, а «Биопроцесс Кэпитал Партнерс» имеет в партнерах известных венчурных гуру - Pitch Jonson и Harold Fitzgibbons. Таким образом, можно сделать вывод, что российскими управляющими компаниями высокое внимание уделяется передаче российским командам компетенций мирового уровня. 
обязательства победителей второго конкурсного отбора

1. Обязательства победителей зарегистрировать ПдУ в ФСФР - до 1 сентября 2008 года

2. Обеспечить привлечение денежных средств инвесторов (пайщиков) $51 \%$ от общего числа инвестиционных паев венчурного фонда.

3. В том числе венчурными специалистами - не менее $1 \%$, при этом каждый специалист обязан приобрести некоторое количество инвестиционных паев.

4. Приобретение в состав имущества венчурного фонда ценных бумаг (долей в уставных капиталах) исключительно инновационных компаний. При этом не более $20 \%$ от размера венчурного фонда может быть потрачено на приобретение ценных бумаг инновационных компаний, имеющих на момент первого приобретения выручку более 150 млн. рублей за 12 календарных месяцев, предшествующих продаже.

5. По истечении 5 лет с даты завершения формирования венчурного фонда его активы должны включать в себя ценные бумаги (доли в уставных капиталах) не менее чем 10 различных инновационных компаний.

6. Вознаграждение управляющей компании, специализированного делозитария, регистратора, оценщика, аудитора, их сумма за финансовый год не должна превышать $2,5 \%$ (без учета ндс).

7. ПдУ может предусматривать выплату вознаграждения управляющей компании "за успех", размер которого не должен превышать 20\% от финансового результата за финансовый год. Вознаграждение за успех подлежит выплате управляющей компании только после выплаты инвесторам суммы денежных средств, на которую были приобретены инвестиционные паи.

8. Оплата паев венчурного фонда возможна только денежными средствами.

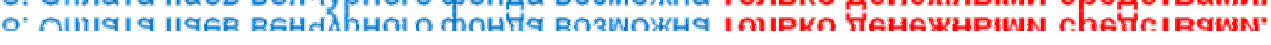

\section{Рис. 12. Обязательства победителей второго конкурсного отбора}

Прием заявок проходил с 1 по 11 апреля 2008 года. К участию в конкурсном отборе допущены 18 управляющих компаний из 20 принятых заявок. Общий спрос на инвестиционные ресурсы на второй конкурсный отбор составил более 48,9 млрд руб.

По сравнению с первым конкурсным отбором во втором на 50\% увеличилось количество претендентов, а общий спрос на инвестиционные ресурсы вырос более чем на 85\%. Эксперты отмечают прогресс качества и проработанности конкурсных заявок по сравнению с первым конкурсным отбором. Резкое увеличение интереса частного сектора к участию в создании венчурной индустрии свидетельствует о росте участников венчурного рынка и работоспособности модели, основанной на механизме частно-государственного партнерства.

Рассмотрение заявок советом директоров ОАО «РВК» запланировано на 27-28 мая 2008 года. Объявление итогов - в 14-дневный срок после подписания протокола заседания совета директоров ОАО «РВК». На третий конкурсный отбор планируется предельная сумма 3 млрд руб. Объявление конкурсного отбора предварительно запланировано на 5 сентября 2008 года, а подведение итогов - на 17-18 декабря 2008 года.

\section{Перспективы развития ОАО «РВК»}

Если говорить о российской модели в целом, то создание венчурных фондов - это только первый шаг и запуск механизма; вместе с тем гораздо более серьезной является задача построения партнерских отношений Российской венчурной компании с венчурными фондами и участниками рынка, интенсификация коллективного обучения, создание высококвалифицированного рынка специалистов и наращивание компетенций мирового уровня. Безусловно, частному сектору необходим наглядный кластер историй успеха, чтобы естественным образом началась цепная реакция по дальнейшему развитию рынка. 
На круглом столе ОАО «РВК» генеральный директор ОАО «РВК» Алексей Валерьевич Коробов сказал, что планируется расширение функций ОАО «РВК» по следующим направлениям:

1. Разработка и внедрение механизма «посевного» инвестирования средств ОАО «РВК» в высокотехнологичные стартапы с реализацией данного механизма через создание сид-фондов (венчурных фондов, имеющих менее жесткие ограничения на максимальный и минимальный размер продаж ценных бумаг инвестируемых компаний по сравнению с существующими правилами ЗПИФ).

2. Разработка и внедрение нефинансовых механизмов поддержки венчурного рынка Российской Федерации через реализацию следующих инфраструктурных программ:

- создание информационной площадки - портала для обеспечения доступа отечественных предприятий к актуальной информации о венчурных рынках, распространения информации о развитии высокотехнологичного и венчурного бизнеса в Российской Федерации и в зарубежных странах;

- формирование с участием ОАО «РВК» системы дополнительного профессионального образования в сфере инновационной деятельности, обеспечивающей уровень подготовки, соответствующий мировым требованиям;

- организация образовательных программ, нацеленных на популяризацию венчурного инвестирования среди предпринимателей, инвесторов и представителей региональных администраций.

\section{Взаимосвязи в основе инновационного развития и потенциальные риски}

Прежде всего обратимся к основам инноваций и приведем определение инновации: это новое в любой сфере - в производстве, в его организации и управлении, в экономике и финансах, во всем. Примеры успехов показывают, что существенная часть инноваций, которые явно удались, - это инновации технологические. Рынок стал глобальным, и в последние десятилетия конкурентоспособность возникает тогда, когда определенная страна и ее компании в чем-то технологически опережают другие. С другой стороны, технологически опережать других можно только на достаточно коротком промежутке времени, пока компания первой выходит на глобальный рынок с каким-то товаром или услугой, которые не просто предназначены для удовлетворения уже имеющегося спроса, но и формируют новый спрос.

Мировая практика показывает, что крупные компании занимаются собственными исследованиями и разработками не по всем возможным направлениям, а лишь по части из них, где у них имеется солидный задел. Однако для того, чтобы такая модель работала, необходимо, чтобы выполнялись два условия: большие компании должны быть заинтересованы в инновациях, а малые - знать об этом и быть уверенными, что впереди в случае успеха их ожидает приз - деньги больших компаний.

Эксперты отмечают следующие риски российской модели: с одной стороны, государство развивает инфраструктуру - поддерживает и технопарки, и инкубаторы, создает новые институты, институт венчурного предпринимательства, выделяет деньги на инновации - через ФЦ НТП и венчурные фонды. С другой стороны, так как нет реального спроса на инновации со стороны больших компаний, государство деформирует рынок, позволяя заниматься инновациями без ориентации на спрос, на коммерциализацию результатов НИОКР, на капитализацию инновационных компаний. На сегодня существуют риски, что инновационным компаниям без разницы, найдет инновация потребителя или нет: государство деньги дает, и хорошо, можно жить, и без капитализации обойдемся. Понятно, что надо двигать крупные компании к тому, что внедрять инновации необходимо, - вот здесь и должна проявиться роль государства.

Главная задача - это породить, а затем укрепить и развить инициативу масс. И эта инициатива не абстрактная, она всегда выразится в деньгах - в личном успехе. Задача - 
стимулировать инициативу и творчество масс по всем направлениям, и помочь в становлении малых инновационных компаний. Если просто развивать малый бизнес в той ситуации, которая есть у нас, то это должен быть торговый бизнес, во всяком случае - не технологический. И перевернуть сознание и убедить, что надо заниматься не этим, а инновациями, - достаточно сложно. Простые механизмы стимулирования инноваций, как создание инфраструктуры и раздача денег, по сути инновационность экономики дестимулируют, так как в отсутствие спроса ведут к ложным целям и неэкономическим критериям решений по инвестициям. Существует риск выключения бизнеса из этих процессов, потому что государственные деньги доступнее, легче, их сложнее контролировать, и они просто замещают частные деньги; к тому же нет частного контроля [Экспертный канал «Открытая экономика», 2008].

Мировой инновационный бизнес, его социотехническая парадигма основываются на личном успехе и стремлении к богатству за счет технологий.

\section{Изменения в российском инвестиционном законодательстве}

6 декабря 2007 года был подписан Федеральный закон № 334, который направлен на совершенствование государственного регулирования деятельности акционерных инвестиционных фондов, управляющих компаний, специализированных депозитариев и негосударственных пенсионных фондов и государственного контроля за осуществлением указанной деятельности, включая механизм ее лицензирования; и на этой основе - на расширение возможностей по инвестированию сбережений, в частности путем введения института квалифицированного инвестора. Целью закона является усиление защиты прав и законных интересов лиц, инвестирующих свои сбережения в инвестиционные фонды и негосударственные пенсионные фонды, а также стимулирование венчурных инвестиций через инвестиционные фонды, акции (инвестиционные паи) которых предназначены для квалифицированных инвесторов (рис.13).

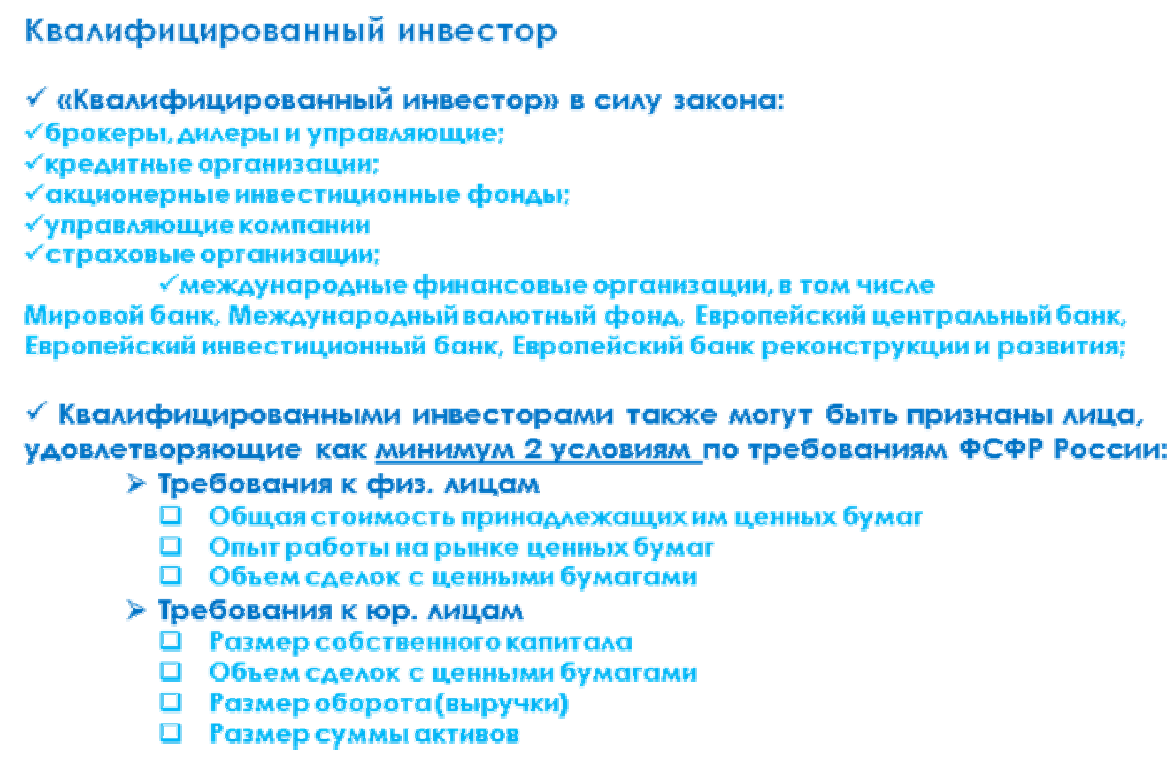

\section{Рис. 13. Квалифицированный инвестор}

Институт квалифицированных инвесторов - это далеко не российское изобретение. Подобный правовой механизм уже много лет работает в США ${ }^{26}$ и Европе ${ }^{27}$. Институт квалифицированных инвесторов должен стать наиболее интересным механизмом исключительно для закрытых паевых инвестиционных фондов особо рисковых

\footnotetext{
${ }^{26}$ Commission Final Rule §230.144A, §275.205-3, Закон об инвестиционных компаниях 1940 года и Закон «о биржевой торговле» 1934 года.

${ }^{27}$ Directive 2003/71/EC of the European Parliament and of the Council of 4 November 2003.

Выпуск \#2(6), 2008

(C) Электронный журнал Корпоративные Финансы, 2008
} 
(венчурных) инвестиций, так как предусматривает такие необходимые рынку новации, как постепенное наполнение фонда деньгами на основе commitment letter и право пайщиков принимать участие в инвестиционном решении при рассмотрении сделок с имуществом фонда на инвестиционном комитете (рис. 14).

\section{фонаы квалифицированных инвесторов}

1. Могут формироваться на условиях коммитмента.

Согласно правилам Аоверительного управления, Аеньги

Поступают в фонА:

- по требованию управмяющей компании

- По каленАарным Аатам и в размере указанном в ПАУ

2. Имеют право созАать инвестиционный комитет из числа пайщиков

- Право оАобрения САелок с имуществом фонАа

3. Могут требовать повышенное вознагражАение

- на фона не распространяется требование о преАельном размере вознагражАения $10 \%$ среАнеГоАовой стоимости чистых активов

4. Ценные бумаги ограничены в обороте

- ценные бумаги обращаются только межау квалифицированными инвесторами

\section{Рис. 14. Фонды квалифицированных инвесторов}

Федеральная служба по финансовым рынкам разработала типовые правила для закрытых паевых инвестиционных фондов. Новая редакция типовых правил для ЗПИФов определяет новые механизмы и возможности, которые предоставляются управляющим компаниям. Так, управляющие закрытыми фондами для квалифицированных инвесторов получили право проводить ряд новых для них финансовых операций. Например, частичную оплату и погашение паев. Это приведет к более эффективному использованию средств, считают управляющие [оммерсанть, 08.05.2008]. 
Таблица 3. Квалифицированный инвестор в России и в ЕС

\begin{tabular}{|c|c|c|}
\hline \multirow{2}{*}{ Показатель } & Юрисдикция & \\
\hline & Евросоюз - квалифицированные инвесторы & Россия - квалифицированные инвесторы \\
\hline Нормативный акт & $\begin{array}{l}\text { Directive } 2003 / 71 / E C \text { of the European Parliament and of the Council } \\
\text { of } 4 \text { November } 2003 \text { [on the prospectus to be published when secu- } \\
\text { rities are offered to the public or admitted to trading] }{ }^{*}[\ldots]\end{array}$ & $\begin{array}{l}\text { Федеральный закон от } 22 \text { апреля } 1996 \text { г. № 39-Ф3 „0 рынке } \\
\text { ценных бумаг» }\end{array}$ \\
\hline Цель квалификации & $\begin{array}{l}\text { Размещение эмиссионных ценных бумаг (акций, облигаций), } \\
\text { предназначенных для квалифицированных инвесторов на рын- } \\
\text { ке ценных бумаг }\end{array}$ & $\begin{array}{l}\text { Обращение ценных бумаг, предназначенных для квалифициро- } \\
\text { ванных инвесторов (ограниченных в обороте ценных бумаг) }\end{array}$ \\
\hline Круг лиц (по умолчанию) & $\begin{array}{l}\text { - Кредитные институты } \\
\text { - Инвестиционные компании } \\
\text { - Другие уполномоченные или регулируемые финансовые ин- } \\
\text { ституты } \\
\text { - Страховые компании } \\
\text { - Институты коллективного инвестирования и их управляющие } \\
\text { номпании } \\
\text { - Дилеры на сырьевых рынках, а такне лица, ноторые не уполно- } \\
\text { мочены и не регулируются, но единственным направлением дея- } \\
\text { тельности которых является инвестирование в ценные бумаги } \\
\text { - Национальные и региональные правительства, центральные } \\
\text { банки, международные и наднациональные институты такие как } \\
\text { МВФ, Европейский цБ, Европейский инвестбанк и другие по- } \\
\text { добные международные организации } \\
\text { - Другие юридические лица, которые не отвечают } 2 \text { из следую- } \\
\text { щих критериев (критерии Мсп): } \\
\text { - среднее количество сотруднинов в течение финансового года } \\
\text { не превышает } 250 ; \\
\text { - суммарный баланс не превышает } 43 \text { млн евро; } \\
\text { - годовой чистый оборот не превышает } 50 \text { млн евро. }\end{array}$ & $\begin{array}{l}\text { - Брокеры, дилеры и управляющие } \\
\text { - Кредитные организации } \\
\text { - Акционерные инвестиционные фонды } \\
\text { - Управляющие номпании инвестиционных фондов, паевых ин- } \\
\text { вестиционных фондов и негосударственных пенсионных фондов } \\
\text { - Страховые организации } \\
\text { - Негосударственные пенсионные фонды } \\
\text { - Банк России } \\
\text { - Государственная корпорация “Банк развития и внешнеэноно- } \\
\text { мичесной деятельности (Внешэнономбанк)" } \\
\text { - Агентство по страхованию вкладов } \\
\text { - Международные финансовые организации, в том числе Миро- } \\
\text { вой банк, Международный валютный фонд, Европейский цент- } \\
\text { ральный банк, Европейский инвестиционный банк, Европей- } \\
\text { ский банк реконструкции и развития } \\
\text { - Иные лица, отнесенные к квалифицированным инвесторам } \\
\text { федеральными законами }\end{array}$ \\
\hline Круг лиц (по признанию) & $\begin{array}{l}\text { - Определенные физические лица: по взаимному согласию го- } \\
\text { сударство-член ЕС может уполномочить физическое лицо, кото- } \\
\text { рое является резидентом государства-члена и ноторое желает } \\
\text { рассматриваться как квалифицированный инвестор, если такое } \\
\text { физическое лицо отвечает, по крайней мере, } 2 \text { из уназанных } \\
\text { нине критериев: } \\
\text { - инвестор проводил сделки существенного объема на рынках } \\
\text { ценных бумаг со средней частотой, по крайней мере, } 10 \text { сделок } \\
\text { в квартал в течение последних } 4 \text { кварталов; } \\
\text { - объем портфеля ценных бумаг инвестора превышает } 0,5 \text { млн } \\
\text { евро; } \\
\text { - инвестор работает или проработал, по крайней мере, } 1 \text { год в } \\
\text { финансовом сенторе на профессиональной должности, требую- } \\
\text { щей знаний инвестирования в ценные бумаги. } \\
\text { - Определенные малые и средние предприятия (Мсп): по вза- } \\
\text { имному согласию государство-член ЕС может уполномочить } \\
\text { Мсп, которые имеют зарегистрированный офис в таком госу- } \\
\text { дарстве-члене и которые желают рассматриваться как квалифи- } \\
\text { цированные инвесторы. }\end{array}$ & $\begin{array}{l}\text { - Физическое лицо может быть признано квалифицированным } \\
\text { инвестором, если оно отвечает любым } 2 \text { из указанных требо- } \\
\text { ваний: } \\
\text { - владеет ценными бумагами и (или) иными финансовыми инст- } \\
\text { рументами, общая стоимость которых соответствует требовани- } \\
\text { ям, установленным ФСФР России. При эом указанный орган } \\
\text { определяет требования к ценным бумагам и иным финансовым } \\
\text { инструментам, которые могут учитываться при расчете уназан- } \\
\text { ной общей стоимости, а также порядок ее расчета; } \\
\text { - имеет установленный ФСФР России опыт работы в россий- } \\
\text { сной и (или) иностранной организации, ноторая осуществляла } \\
\text { сделки с ценными бумагами и иными финансовыми инстру- } \\
\text { ментами; } \\
\text { - совершило сделки с ценными бумагами и иными финансовы- } \\
\text { ми инструментами в количестве, объеме и в срок, ноторые уста- } \\
\text { новлены ФСФР России. } \\
\text { - Юридическое лицо может быть признано квалифицирован- } \\
\text { ным инвестором, если оно является коммерческой организаци- } \\
\text { ей и отвечает любым } 2 \text { из уназанных требований: } \\
\text { - имеет собственный капитал в размере, установленном ФСФР } \\
\text { России; } \\
\text { - совершило сделки с ценными бумагами и иными финансовы- } \\
\text { ми инструментами в количестве, объеме и в срок, которые уста- } \\
\text { новлены ФСФР России; } \\
\text { - имеет оборот (выручку) от реализации товаров (работ, услуг) } \\
\text { в размере и за период, ноторые установлены ФСФР России; } \\
\text { - имеет сумму активов по данным бухгалтерсного учета за по- } \\
\text { следний отчетный год в размере, установленном ФСФР Рос- } \\
\text { сии. }\end{array}$ \\
\hline
\end{tabular}


В таблице 3 представлено сравнение понятий и требований предъявляемых в Евросоюзе и в России к юридическим и физическим лицам по признанию их квалифицированными инвесторами, а также представлен круг лиц, которые считаются квалифицированными инвесторами в силу закона [РЦБ. Квалифицированный инвестор, 2008].

В рамках круглого стола ОАО «РВК», проводившегося 4 апреля 2008 года, обсуждались законодательные инициативы, и то, какие ограничения могут встретить участники рынка и какие требования будут предъявляться к инвесторам и венчурным специалистам в рамках закрытых паевых фондов особо рисковых (венчурных) инвестиций [Круглый стол ОАО «РВК», 2008]. Выяснилось, какие риски и какие дополнительные возможности получают участники рынка с вступлением в силу соответствующих поправок. Далее представлены проекты финансовых требований, которые предъявляет ФСФР России к физическим и юридическим лицам для признания их квалифицированными инвесторами [Пресс-служба РВК, 2008] (рис.15, 16.):

\section{1. Физическое лищо может быть признано квалифицированным инвестором, если оно} отвечает любым двум требованиям из указанных:

1) владеет отвечающими требованиям пункта 2.4 настоящего Положения ценными бумагами и (или) иными финансовыми инструментами, общая стоимость которых, рассчитанная в порядке, предусмотренном пунктом 2.5 настоящего Положения, составляет не менее 3 миллионов рублей.

2) имеет опыт работыв российской и (или) иностранной организации, которая осуществляла сделки с ценными бумагами и (или) иными финансовыми инструментами:

не менее 1 года в случае, если такая организация является квалифицированным инвестором в силу пункта 2 статьи 51 Федерального закона «О рынке ценных бумаг»;

не менее 1 года в случае, если физическое лицо имеет квалификационный аттестат специалиста финансового рынка;

не менее 3 лет в иных случаях.

3) совершало ежеквартально не менее чем по 10 сделок с ценными бумагами и (или) иными финансовыми инструментами в течение последних 4 кварталов, совокупная цена которых за указанные 4 квартала составила не менее 300 тысяч рублей.

Рис. 15. Квалифицированный инвестор: требования к физическим лицам 
2.2. Юридическое лищо может быть признано квалифицированным инвестором, если оно является коммерческой организацией и отвечает любым двум требованиям из указанных:

1) имеет собственный капитал не менее 100 миллионов рублей:

2) совершало ежеквартально не менее чем по 5 сделок с ценными бумагами и (или) иными финансовыми инструментами в течение последних 4 кварталов, совокупная цена которых за указанные 4 квартала составила неменее 3 миллионов рублей;

3) имеет оборот (выручку) от реализации товаров (работ, услуг) по данным бухгалтерской отчетности за последний отчетный год не менее 1 миллиарда рублей:

4) имеет сумму активов по данным бухгалтерского учета запоследний отчетный год не менее 2 миллиардов рублей.

\section{Рис. 16. Квалифицированный инвестор: требования к юридическим лицам}

Следует отметить, что требования российского законодательства к квалифицированным инвесторам ниже зарубежных аналогов в США и ЕС. Хотя наблюдается несоответствие, например, региональных венчурных фондов данным критериям, так как инвесторами в региональные фонды является местная администрация, которая не подпадает под определение квалифицированного инвестора. В целом законодательные инициативы должны учитывать все направления государственной инновационной политики, реализуемой исполнительной властью. Безусловно, эти законодательные новации требуют времени для внедрения. Участники рынка и регулятор должны накопить практический опыт использования данного института, и вскоре рынок отреагирует и приспособится к новым инструментам.

\section{Результаты второго конкурсного отбора}

В рамках XII Петербургского международного экономического форума 8 июня 2008 года совет директоров ОАО «РВК» принял решение о победителях второго конкурсного отбора. По итогам второго конкурсного отбора среди 18 управляющих компаний были объявлены 5 победителей [Набиуллина Э.С., 2008]. В их число вошли:

1. ОАО «Альянс РОСНО Управление Активами» - 3061 млн рублей.

2. ООО «Максвелл Эссет Менеджмент» - 3061 млн рублей.

3. ЗАО «Лидер» - 3000 млн рублей.

4. ООО «Управляющая компания «Север Эссет Менеджмент» - 1800 млн рублей.

5. ЗАО Управляющая компания «ЦентрИнвест» - 2000 млн рублей.

Общий спрос на инвестиционные ресурсы составил более 48 млрд рублей. Объем средств ОАО «РВК», которые планируется передать в доверительное управление по результатам конкурсного отбора, составил более 6,3 млрд рублей. По всем показателям имеется неоспоримая положительная динамика по сравнению с первым конкурсным отбором (табл. 4). 
Таблица 4. Динамика показателей конкурсных отборов

\begin{tabular}{|c|c|c|c|}
\hline $\begin{array}{l}\text { Показатели, } \\
\text { млрд руб. }\end{array}$ & $\begin{array}{c}\text { Первый } \\
\text { конкурсный } \\
\text { отбор }\end{array}$ & $\begin{array}{c}\text { Второй } \\
\text { конкурсный } \\
\text { отбор }\end{array}$ & Динамика \\
\hline $\begin{array}{c}\text { Максимальная } \\
\text { конкурсная сумма }\end{array}$ & 4,8 & 9,0 & $+88 \%$ \\
\hline $\begin{array}{l}\text { Общий спрос рынка на } \\
\text { инвестиции ОАО «РВК» }\end{array}$ & 26 & 48,9 & $+88 \%$ \\
\hline Количество претендентов & 12 & 18 & $+50 \%$ \\
\hline $\begin{array}{c}\text { Количество } \\
\text { венчурных фондов }\end{array}$ & 2 & 5 & $+150 \%$ \\
\hline $\begin{array}{c}\text { Общая капитализация } \\
\text { венчурных фондов }\end{array}$ & 6,061 & 12,922 & $+113 \%$ \\
\hline
\end{tabular}

\section{Резюме российской государственной модели}

ОАО «РВК» - это успешный институт инновационного развития, который исполняет уникальную роль по созданию венчурной индустрии России. Развитие ОАО «РВК» идет ускоренными темпами, доказательством чему является активный инвестиционный процесс созданных венчурных фондов.

«Мы будем добиваться внедрения инновационных подходов во все сферы жизни, строить самые передовые производства, модернизировать промышленность и сельское хозяйство, создавать мощные стимулы для частных инвестиций и в целом стремиться к тому, чтобы Россия прочно утвердилась среди лидеров технологического и интеллектуального развития» [Медведев Д.А., 2008].

Анализируя активные действия государства по стимулированию инновационной активности и развитию венчурного капитала в 2006-2008 годах, следует отметить роль модели венчурного финансирования, которую избрало государство. Создание РВК на основе мирового опыта успешной реализации подобной государственной задачи в Финляндии и Израиле и особое внимание Президента РФ к проблеме формирования инновационной экономики оставляют надежду на серьезное улучшение и оздоровление сектора инноваций и формирование культуры ведения венчурного бизнеса в России, на появление новых рабочих мест и профессиональных специалистов в венчурной области.

\section{Выводы}

1. Спецификой российского пути развития венчурного финансирования является значительная роль государства в процессе становления. Государству необходимо помогать в становлении венчурного инвестирования следующими методами:

а) выделение денежных средств на развитие института финансирования инноваций;

б) выделение денежных средств на покупку результатов работы венчурных компаний.

Государство должно научиться включать частный бизнес в решение государственных задач за счет создания привлекательных условий: венчурной инфраструктуры, внесения изменений в законодательство, регулирующее трастовые отношения, фидуциарную 
ответственность, введение поправок в закон об инвестиционных фондах, изменения соотношения риск-доходность и др.

2. В России впервые создается модель государственного стимулирования инноваций и венчурного бизнеса такого масштаба. Правительством создано ОАО «Российская венчурная компания», проведен первый конкурсный отбор юридических лиц для передачи им в доверительное управление средств ОАО «РВК». Сформированы два венчурных фонда ЗПИФ ВИ «ВТБ - Фонд Венчурный», «Биопроцесс Кэпитал Венчурс». Только в 2008 году планируется проивестировать больше половины капитализации фондов, что составляет более 3 млрд руб. Объявлены 5 победителей второго конкурсного отбора с общей капитализацией фондов более 12,9 млрд руб.

3. Планируется, что всего с участием средств РВК в течение 2007-2009 годов будет создано 8-12 новых венчурных фондов с совокупным капиталом порядка 30 млрд руб. Эти фонды обеспечат венчурным капиталом до 200 новых инновационных компаний и станут косвенным катализатором создания еще порядка 1000 компаний.

4. Частный бизнес должен подстроиться, адаптироваться к российской венчурной модели: научиться эффективно увеличивать стоимость компаний, ориентироваться на капитализацию как главный критерий успеха, получить опыт ведения венчурного бизнеса и выйти на мировой уровень.

\section{Список литературы}

1. Аммосов Ю.П. Венчурный капитализм: от истоков до современности. СПб.: Феникс, 2005. - c. 56, 258, 276.

2. Каширин А. И., Семенов А.С. Венчурное инвестирование в России. М.: Вершина, 2007. - c. 144-145.

3. Симонян К. Э. Инвестиционные механизмы развития венчурного предпринимательства в России. М.: 2006. - с. 4.

4. Avnimelech G., Teubal M. Venture Capital policy in Israel: a comparative analysis \& lessons for other countries, 2002, p.19.

5. Пеникас Г., Маленко А. Высшая Школа Экономики// Деловой журнал ChinaPRO Весь Китай, № 1, 01.04.2005.

6. United Nations, Economic Commission for Europe, Synopsis of good practices in financial intermediation in support of innovation and knowledge-driven development. 05.12.2007.

7. Гладких И. РАВИ, www.rvca.ru, 2006.

8. Послание Президента РФ В. В. Путина Федеральному Собранию РФ от 10 мая 2006 г. Российская газета, № 97, 11.05.2006.

9. Сводный план по реализации послания Президента РФ. Распоряжение № 838-р от 7 июня 2006 г. Пункт 10. С. 5.

10. РосБизнесКонсалтинг., 09.06.2007.

11. РБК daily. 17.04.2007.

12. Круглый стол ОАО «РВК», 07.03.08.

13. Круглый стол ОАО «РВК», 25.03.08.

14. Экспертный канал «Открытая экономика», 28.04.2008.

15. Газета «Коммерсантъ», № 78 (3895). 08.05.2008.

16. РЦБ. Квалифицированный инвестор. № 5 (356), 2008. С.20.

17. Пресс-служба РВК. Проект «Положение о порядке признания лиц квалифицированными инвесторами». http://www.rusventure.ru/?p=56.

18. Круглый стол ОАО «РВК», 04.04.2008.

19. Набиуллина Э.С.. Заседание Президиума Правительства РФ 09.06.2008.

20. Медведев Д.А. Выступление на церемонии вступления в должность Президента России. 07.05.2008. 